\title{
Buddhism and Kalmyk Secular Law in the Seventeenth to Nineteenth Centuries
}

\author{
Mergen S. Ulanov
}

Department of Philosophy and Cultural Studies, Kalmyk State University

Valeriy N. Badmaev

Department of Philosophy and Cultural Studies, Kalmyk State University

\author{
Edward C. Holland
}

corresponding author

Department of Geosciences, University of Arkansas

echollan@uark.edu

\begin{abstract}
Buddhism endorses a set of rules and standards of conduct set out in the religion's canonical texts. The text of the 1640 Steppe Code, both a peace treaty among the Mongols and an attempt at alliance building vis-à-vis the Manchus, also reflects the adaptation of the ethical norms of Buddhism to secular law and political relations. Secular law among the Kalmyks further evolved in the eighteenth and nineteenth centuries. The Toktols issued by Khan Donduk-Dashi in the eighteenth century addressed a wide range of religious and secular elements in Kalmyk life, while also serving to strengthen the moral authority of the Buddhist clergy. Further revisions to Kalmyk law and the position of Buddhism within the secular system were promulgated at the Jinjil assembly in 1822. The Kalmyks' inclusion of religious provisions in secular law helped to strengthen the connection between Buddhism and Kalmyk society, consolidating the normative role of religion as the basis for secular conduct and action.
\end{abstract}

\section{Keywords}

Buddhism - Buddhist law - secular law - Kalmykia 


\section{Introduction}

Religion as a worldview is not limited to the realm of belief and the numinous (Eliade 1959). Its influence is widespread, and extends beyond any delimited religious community to include society in general. Like religion, law-as a set of rules established and enforced by social and/or political institutionsserves as a regulator of norms, reflecting the moral values central to a society and defining how such values are oriented. At the same time, the interaction of religion and law reflects their mutual influence on one another; in fact, religion and law are not necessarily distinct social institutions. This is particularly true in traditional societies. Legal systems in ancient and medieval times commonly incorporated religious rules and norms. Canonical law had a significant influence on the development of legal systems in the ancient Middle East; the religious component in the laws of Hammurabi includes the invocation of divine patronage in the prologue (Prince 1904). Prince also recognises the parallels between Hammurabi's Code of Laws and the Mosaic Code articulated in the Old Testament. The ancient Jews derived from the Ten Commandments ethical-legal norms of a more concrete nature that in turn regulated various spheres of social life (Bachinin 2008). The Old Testament further reflects the idea that all religious commandments are attributed to the supernatural. These norms were understood as something eternal, absolute, and extending to the political and cultural life of society. Only later, with the onset of modernity, are religion and law more fully distinguished. ${ }^{1}$ Despite this process of differentiation, belief systems often play a foundational role in the establishment of modern legalistic traditions and socio-political organisation (Casanova 1994).

Canonical law has played a similar role in the legal codes of Buddhist societies, particularly among the Mongolian peoples (Bachinin 2008; Ulanov et al. 2016). The term 'canon' denotes the rules of conduct sanctioned by councils or individual hierarchs within religious institutions. In accordance with the canon, the behaviour of individuals is deemed either virtuous or sinful. Under Buddhist canonical law, rules of behaviour were set forth in key texts associated with the Vinaya; this ethical code applied to the Buddhist community of monks, termed the Sangha. With the development and spread of Buddhism from its historical heartland in India, several variants of the Vinaya took hold in different regions. Tibetan Buddhists follow the Vinaya School of Mulasarvastivada (one of three surviving Vinaya lineages, along with the

1 This claim is mainly valid in the west, where secularisation led to the separation of church and state. In the Muslim Middle East, this differentiation is still an incomplete process, as was also the case for Kalmyk society in the period discussed in this article. 
Theravada and Dharmaguptaka), which requires monks to adhere to 253 vows or rules. Mongolian Buddhism is generally derived from the Gelug and Kagyu lineages in Tibetan practice, although the religion included syncretic elements that drew from shamanism. The prima facie acceptance of a direct historical link in Buddhist practice between Tibet and Mongolia was the product of the historiography of the Manchu period (Elverskog 2006).

This article considers the role of Buddhism as a religious worldview in the formulation of secular law among the Kalmyks. ${ }^{2}$ The Kalmyks incorporated elements from the ancient civilisations of Tibet, China and India into their traditions, including their legal system and religious worldview, although the precise nature of this influence is less studied (Ulanov 2009). For example, there is little contemporary Russian-language scholarship on how Buddhism influenced the genesis of Kalmyk law, though prior to the 1917 revolutions some attention was paid to the Tsaajin-Bichig - the Mongol-Oirat laws of 1640 also known as the Ik Tsaaz or the Steppe Code (see, for example, Golstunskiy 1880; Gurlyand 1904; Leontovich $1879 ; 1880){ }^{3}$ Rather, contemporary scholarship is mainly devoted to the integration of the Kalmyks into the Russian empire (Schorkowitz 1992; 2001). Khodarkovsky positions the Kalmyks as a borderland people and is generally interested in their treaty relations with the imperial centre, including

2 As discussed later in the article, the term 'Kalmyk' predates the migration of members of the larger Oirat tribe to the steppeland around the lower Volga Basin in the early seventeenth century. Over the course of the nineteenth century, however, these migrants adopted this term to describe themsevles (Khodarkovsky 1992). In the article, we use the term 'Oirats' to reference the group prior to the seventeenth century, as well as those who stayed in western Mongolia. The term 'Kalmyk' is used to refer to those Oirats who migrated west to steppe north of the Caspian Sea when referencing the group after the early seventeenth century.

3 After its drafting in 1640, the Steppe Code was brought to the southern Volga region by Kho Örluk, who led the Torghut tribe of the larger Oirat group on its westward migration. B.M. Bakunin, on behalf of the Collegium of Foreign Affairs, made the first Russian translation of the Steppe Code in 1724 (Riazanovsky 1965). The 1822 Jinjil decrees discussed later in the article were the product of a meeting of Kalmyk elites convened in response to a request made by the Russian Foreign Ministry to adapt the Steppe Code to current circumstances; the basis for this discussion was, according to Riazanovsky (1965: 77), 'a similar translation' to the one produced by Bakunin.

In this article, we rely on the translation of the Steppe Code of S.D. Dylykov (1981). Sergeev \& Sergeev's (1998) text, published in Elista, the capital of the republic of Kalmykia, provides Russian-language translations of the Steppe Code, the Toktols of Donduk-Dashi, and the Jinjil decrees. We use this volume for the Toktols, which the authors reproduce from the earlier translation of Golstunskiy (1880). Leontovich (1880) provides Russian-language translations of the legal elements from the Jinjil decrees; we rely on his translation of the religious elements of this final document in our text. 
a 1655 shert' that the Kalmyk tayijis signed and the 1697 agreement that secured Russian assistance for the Kalmyks against raids by the Cossacks and Bashkirs (Khodarkovsky 1992; 2002). ${ }^{4}$ Our contribution considers the role of Buddhism in the formulation of Kalmyk secular law-the influence of Buddhist thought in the drafting of the law and the provisions relating to the Buddhist clergy found in Kalmyk legal codes.

In tracing this historical evolution, the article proceeds as follows. We first offer a concise history of the Oirats, including their origins from the Mongol Empire and migration to the lower Volga Basin in the early seventeenth century. The legal system adopted by the Oirats has its origins in both the imperial system of the Mongols and Buddhism as a religious tradition. The foundational statement of this legal system is the 1640 Steppe Code, which was both a peace treaty among the Mongolian peoples and an alliance-building agreement that incorporated ethical norms from the Buddhist religious tradition into its legal content. Subsequent revisions to secular law include the Toktols 5 issued in the mid eighteenth century and the Jinjil decrees of 1822 . Our central argument is that, throughout the evolution of the Kalmyks' legal system, Buddhism has played in key role in the development of secular law. The article's conclusion reflects on this continuing influence in the present day.

\section{The Oirats in the Mongolian World}

The Oirat are a western Mongolian group that is historically viewed as not directly descended from Genghis Khan, although in fact the group existed long before the emergence of the Mongol Empire. The group was first referred to as Kalmyks by their Turkic neighbours, in reference to the Oirats' retention of paganism when neighbouring groups adopted Islam (Boyle \& Wheeler 2012). This is, however, one of several competing theories on the origins of the name. Despite the lack of direct descent from Genghis Khan, the early history of the Oirats is closely linked to that of the Mongol Empire.

4 The term shert' is generally defined as an 'oath of allegiance' (Khodarkovsky 2002), although the Kalmyks themselves did not understand them as such; from the Kalmyk perspective, they are more appropriately defined as 'agreements of mutual assistance'. We thank one of the paper's anonymous reviewers for clarification on this point. The generic term tayiji refers to princes who were subordinate to the Khung-tayiji ('swan prince'); the tayijis played a role in the administration of Kalmyk society through the zargo court (see further discussion of this institution below; Krader 1963).

5 The Toktols refer to a series of legislative edicts promulgated by Donduk-Dashi during his leadership of the Kalmyk Khanate from 1741 to 1761 (Krueger 1972). 
The Empire's customary law was articulated as the great Jasag (Mong.) during the time of Genghis Khan; an assembly of noblemen in 1206 is the commonly given date of its drafting (on the history of Mongol law, see Riazanovsky 1931; on the literature interrogating the provenance of the Jasag, see Morgan 2005). There is no complete text of these laws; rather, what remains is fragmentary, and the text that was written down was done so after Genghis Khan's death in 1227 (Krader 1965; Vernadsky 1938). Morgan (1986: 168) writes of the historical literature on the Jasag: 'There seems to have been very little unanimity [...] over what it contained'. Subsequent articulations of Mongol customary law incorporated elements of Tengrism, the shamanistic belief system that preceded Buddhism and Islam in parts of Central Asia (despite this historical legacy, there is no clear consensus on the definition of this spiritual worldview). Official imperial documents opened with a consistent formula, appealing to the sacred: 'By the powers of the eternal sky'.

With the gradual fragmentation of the Mongol Empire into independent khanates, the importance of the Jasag began to recede. The more localised legal traditions that emerged in its stead were influenced by both Buddhism, among the Mongolian peoples of Inner Asia and the Northern Yuan following Kublai Khan's invitation to Phagspa Lama in the 1270s, and Islam, in the successor Khanates of the Golden Horde, the Chagatai, and Shaibanid from the early fourteenth century onwards. Chingisid khans granted privileges to the Buddhist religion, incorporated religious hierarchies into their governing structures and accepted Buddhism as their personal religion of practice. At the same time, patronage of Buddhism was most commonly rationalised as a mechanism of control used by the Chingisid khans over their Buddhist subjects. As Pochekaev (2013: 33) writes, 'Buddhism was not an official state religion, its hierarchy was not part of the imperial system of government, and it did not have any power or influence over representatives of other faiths'.

The Oirat confederation-referred to as the Dörben Oirat and consisting of four smaller tribes (the Dzungar, Dorbets, Torghut and Khoshut)—ruled Mongolia for a little more than 100 years, until $155^{2}$ (Grousset 1970; Krader 1963). At that time, the Khalkha Mongols under the leadership of Altan-Khan regained control of the east. The Oirats were pushed back first to the Kobdo region (today, Khovd) and then further west, to the upper Yenesei River (today, Tyva). This forced return created population pressures on resources and land for the confederation's tribes, and the Torghuts under the leadership of Khö Orluk and a smaller grouping of Dorbets under Dalai-tayiji made a transcontinental journey from Inner to Western Asia in the early part of the seventeenth century.

Incorporated into the Russian state, the Oirats-who came to be known as the Kalmyks - occupied the vast steppe in the polity's south along the lower 
Volga River north of the main Caucasus mountain range. As a result, a vassal nomadic polity emerged to Russia's south. The Kalmyks by this time practised Gelug Buddhism, although shamanism was still pervasive and influential. In the early contact period (from the early seventeenth century to the start of the eighteenth), relations with Russia were characterised by divergent expectations on both sides; these differences eventually resulted in the exodus of most of the Kalmyks back to their historic homeland in ${ }^{1771}$ (Khodarkovsky 1992).

\section{The Influence of Buddhism on the Tsaajin-Bichig}

The first written legal code used by the Oirats was the Tsaajin-Bichig MongolOirat law adopted in 1640. This legislation is variously known as the Ik Tsaaz, the Steppe Code, and the Mongol-Oirat Charter. ${ }^{6}$ The congress at which these laws were passed gathered together Oirat and Mongol nobles — the khurultay — and was held at the initiative of the Dzungarian ruler Erdeni Batur Khung-tayiji. The aim of the congress was to regulate relations between the Oirat (Western Mongol) and Khalkha (Eastern Mongol) rulers and to spur their unification in the face of an intensifying threat from Manchuria (which became the Qing dynasty in 1644). The 1637 conflict between the Khalkha and the Oirat-led by Tsogt Khung-tayiji and Güüshi Khan Törü-Baikhu, respectively-had further entrenched this internal split (Munkh-Erdene 2010). In turn, the reason for convening the congress was the need to overcome fragmentation and disunity among the Mongolian peoples. Although it was not possible to unite all the Mongolian lands in the end, this political course resulted in the formation of the Dzungar Khanate $(1634-1758)$ in what is today western Mongolia and northern Xinjiang, the Kalmyk Khanate (1630-1771) in the lower Volga region and the Khoshut Khanate (1642-1717) in northern Tibet (Sneath 2007; Miyawaki (1984), however, questions the use of the term khanate to describe these polities). The laws of 1640 served as one basis among others-including warfare, trade and tributary systems - for the political, legal and socio-cultural development of these Oirat polities. ${ }^{7}$ Krader (1963: 128) endorses the assumption that the Steppe Code influenced the Kalmyk populations near the Caspian

6 We use the names Steppe Code and Tsaajin-Bichig interchangeably in the remainder of the text.

7 Khodarkovsky (1992: 15) has questioned the application of the term khanate to the Oirat confederation; it implies 'the existence of at least rudimentary state structure, with some urban centers [sic], defined territory, sovereign jurisdiction, and effective legal authority', whereas the Oirat were a 'totally nomadic society' with no permanent settlements. 
Sea: 'the code bore equally on the Kalmuks of the Volga as upon the Oirats of Dzungaria, inasmuch as there was considerable movement between the two areas, and the peoples involved considered themselves to be one'.

Buddhism's role in the formulation of the Tsaajin-Bichig is contested. Leontovich (1879) and Riazanovsky (1931) argue that Buddhism is one of the main sources for the Steppe Code. Riazanovsky (1931: 44), for example, describes the code's 'attitude toward religion as most reverential and fervent'. The preamble demonstrates the influence of Buddhism in content, if not jurisprudence; the opening expresses deference to the Buddha and the great Tibetan lamas: Tsongkhapa, the Dalai Lama, and the Panchen Lama (among others: Dylykov 1981: 13). However, other scholars suggest that the influence of Buddhism on the document was negligible, and that the creators of these laws relied in the main on customary law in their formulation (Golstunskiy 1880; Gurlyand 1904). The compromise viewpoint, articulated by Sazykin (1980) and Kurapov (2010), suggests an indirect influence of Buddhism through the participation in the congress of representatives of the Buddhist clergy; Zaya Pandita served as an intermediary between the Oirat and the Khalkha in organising the 1640 khurultay. The authorities in Dzungaria and Mongolia were generally amenable to Buddhism, and particularly to the Yellow Hat (Gelug) school of Tibetan Buddhism. In addition to the conclusion of a peace treaty among the Mongolian peoples, the adoption of the Steppe Code incorporated the ethical norms of the Buddhist religion, vis-à-vis shamanism, into Mongolian public life.

If the influence of Buddhism on the drafting of the laws is difficult to determine precisely, then the content of the Tsaajin-Bichig makes a clearer statement in defence of the interests of the Buddhist church. The sixth provision of the code proscribed violence against religious communities; it referred specifically to violence against aimaks ${ }^{8}$ organised as monasteries, which was considered a serious crime with substantial penalty: 'If anyone commits murder and robbery against the servants of religion in the monastery, then take from him one hundred suits of armour, one hundred camels, and a thousand horses' (Dylykov 1981: 14). ${ }^{9}$ This element of the Steppe Code, 'by making religious

8 An ulus - the largest grouping in Kalmyk society — was composed of aimaks to form a kinship group headed by a tayiji (a prince serving below the Khung-tayiji). Krader (1963) defines aimaks as smaller groupings determined by patrilineal descent, ranging between 150 and 300 tents in size, and led by zaisangs, who were appointed on the basis of either kinship or merit.

9 Sergeev \& Sergeev (1998: 25) translate the last of these stipulations using the term tabun, which refers to a herd of horses rather than an individual animal. 
discrimination punishable, not only encouraged religious tolerance but also provided a legal protection to various (Buddhist) religious sects' (MunkhErdene 2010: 276). However, a similar punishment was articulated for attacking aimaks without any religious affiliation. Among the Kalmyks, distinct from the Buryats (another Buddhist population within the Russian imperial sphere), there also existed so-called Shabinars' aimaks, whose representatives were attached in service to one or another monastery; ${ }^{10}$ their legal status was generally with the former class of aimaks, those affiliated with the clergy.

In addition to this proscription against violence, the Tsaajin-Bichig included provisions on the protection of religious property. The clergy were exempt from public work, such as forced labour or military service, as well as from the obligation to provide horses through the traditional cart and horse service, the podvod. In turn, officials were forbidden to take, for example, carts and horses from members of the clergy: 'If someone takes a cart from lamas or bandi, take one cow from him; if, for horse and cart service (podvod), someone takes a sanctified (osvyashshennui) horse, in turn take a horse from them' (Dylykov 1981: 16). The penalty for insulting clergymen was also explicitly stipulated: 'For insulting a gelung, impose a fine of three nines [27 cattle]; and for striking [a gelung], take five nines [45 cattle]' (Dylykov 1981: 16)." The Steppe Code further included provisions aimed at strengthening the moral foundations of the Buddhist clergy: 'From a toyon who arbitrarily breaks the vows he has taken, take half of his property and livestock' (Dylykov 1981: 16). ${ }^{12}$

Notably, the Steppe Code is distinguished by a values system rare for early modern legal codes. The relatively mild nature of punishments is indicative of the Buddhist influence, and the Steppe Code only rarely stipulates the death penalty as a form of punishment. It was to be applied only in the case of abandonment in battle, as well as for not warning of attack by outsiders (Klochkov 1978: 267). The mediating influence of the Buddhist principles of goodness and tolerance is also apparent in the code's articles on adultery. For example, a woman who committed adultery was punished with only a fine paid to the noyon (a title given to sons who were not in line for hereditary succession; noyons could, however, declare independence from their line). In comparison,

10 Gazizova (2009: 25), following Bakaeva (1994), defines shabinars as 'serf monks dependent on a particular khurul'.

11 A gelung refers to an ordained monk who followed the 253 vows of the Mulasarvastivada Vinyaya. At the same time, there is no clear definition in the Steppe Code of what constitutes a punishable insult.

12 A toyon is defined by Dylykov (1981: 38 ) as '[someone from a noble family] who took a monastic vow' 
according to the Jasag adultery was punishable by death. Such mild punishment for adultery sharply contrasted with the legal norms of neighbouring Muslim polities, where adultery, according to Sharia law, was punishable by the death penalty (Pochekaev 2013).

The Mongol-Oirat laws of 1640 aimed to spread Buddhism among the masses, who at that time were largely influenced by shamanism. In turn, the laws penalised shamanic practice. For those initiated into the shamanic order, the laws stipulated a large fine in the form of a horse. The code also indicated that if someone found an ongon (a protector spirit and its representation), then it should be handed over; if not, a fine was imposed. Shamanic rituals were also condemned: 'If a shaman casts a spell on a high-class man, take five (cattle); and if [he does the same on] a low-class man, take two horses' (Dylykov 1981: 28). Other articles in the code forbade shamans to use birds and animals for ritual sacrifice. For the use of ducks, sparrows and dogs, for example, the fine of one horse was imposed; if snakes were used-'except those that are found on Alak-ula mountain'- then the fine was either two arrows or a knife (Dylykov 1981: 29). It should be noted that the Buddhist teachings emphasise the importance of ahimsa, which is understood as a rejection of violence against living beings; Buddha, who opposed perceived cruelty towards living things, condemned ritual sacrifices.

\section{Buddhism and the Toktols of Donduk-Dashi}

An important stage in the further development of the Kalmyk's legal system were the legislative acts of Khan Donduk-Dashi, issued from the early $1740 \mathrm{~s}$ and referred to as the Toktols. ${ }^{13}$ After 1708 the Kalmyk leader-at that time, Ayuki-was addressed as khan by Russian authorities (Ayuki had been khan since either 1690: Lytkin 1969, or 1697: Ahmad 1970). As the Kalmyk legal system continued to develop it was increasingly defined by its position vis-à-vis the Russian empire. For the Kalmyk Khanate on Russia's southern steppe, the Toktols supplemented the 1640 Steppe Code and responded to the new realities in the social and political life of the group, while also acknowledging the need for administrative reform (Schorkowitz 1992). Particularly relevant to our argument, the Toktols addressed the strengthening position of Buddhism as a

13 Galdan Khung-tayiji issued supplements to the Steppe Code in 1678. These additions were oriented towards civil law, although the third article in the second $u k a z$ (decree) stipulated that 'when considering conflict cases between Oirats and Khotonami (Muslims), who is right and who is not, undertake an investigation' (Dylykov 1981: 31). 
source of cultural identity and socio-political organisation within the Kalmyk polity.

The Toktols, like the Steppe Code, begin by acknowledging Buddhist deities Manjushri and Vajradara, as well as the Oirat Buddhist monk, Lama Zaya Pandita. ${ }^{14}$ The text proceeds to mention representatives of the Kalmyk clergy who blessed the legislation's creation and likely participated in its development; this includes Rajamba Sanjay-Djamtsou, Lama Baldan-Gabtsu, Gelung Abo and Lama Lonric-Tsordji, among others (Sergeev \& Sergeev 1998: 68).

The legislation itself dealt with a wide range of issues related to the religious life of the Kalmyks. The Toktols included a number of provisions specifically related to spirituality and strengthening the moral authority of the Buddhist clergy. Leaving the monastic order of one's own accord was a punishable offence. The Toktols also defined responsibility for the use of wine and non-observance of fasting by the Buddhist clergy. Violation of monastic vows proscribing alcohol was punishable by a fine paid to the witness: 'He who sees a gelung drinking wine [...] take from the drunk a three-year-old horse' (Sergeev \& Sergeev 1998: 68). The fine was less-a three-year-old sheep-for getsuls (novice monks who have not yet taken their full vows). The fine for further violations was expulsion from the monastery. ${ }^{15}$ The pronouncement of punishment for violations of religious customs in secular law indicated a purposeful and consistent policy aimed at strengthening the status of the Buddhist church in Kalmyk society.

Monks, upon accepting their vows, were required to observe their spiritual duty strictly, specifically the four fundamental vows in the Pratimoksha Sutra: not to kill, not to lie about the attainment of supernatural powers, not to cheat, and to maintain celibacy (Keown 2004). The Vinaya is distinguished by its strictness with respect to these four vows. It is noted in the Toktols that if these fundamental vows - common to both getsuls and gelungs - are violated, then the monastic initiation will be terminated. A monk who commits one of these four most serious offences automatically loses his monastic title and can no longer join the community. The Toktols addressed the fundamental vows in its development of secular law by requiring the payment of a 'four-year-old camel to the khurul' in the case of gross violation of any of these four vows

14 Zaya Pandita introduced the Oirat script, modified from Mongolian writing, in 1648 (see Krueger 1975 regarding 1648 as the date for the script's introduction).

15 The religious hierarchy in Kalmyk Buddhism included from lowest to highest rank: bandi (also referred to as manzhi), getsuls (not a full monk; required to observe 36 vows in the Pratimoksha Sutra); and gelungs (a full monk required to observe the 253 vows in the Pratimoksha Sutra). 
(Sergeev \& Sergeev 1998: 68). The violation of chastity is separately described: 'Who among the clergy marries must divorce; if he does not leave his wife, then do not allow him to enter the temple, do not allow him to perform rites, and tax him' (Sergeev \& Sergeev 1998: 69).

A key difference between the Toktols and the Steppe Code is the fact that in the latter document attention is paid to the spiritual life of laymen. The Toktols determined the punishment for violations of the Sojong vows, including the observance of fasting. Sojong refers to the practice of purification and the restitution of broken promises. Usually, members of the monastic community practice Sojong twice a month, to restore broken Vinyaya vows. Buddhist laypersons also perform this practice of purification. ${ }^{16}$ Certain days are devoted to the performance of Sojong: during the full moon (the 15th lunar day) and the new moon (the 3oth lunar day). These principles fully coincide with the vows that monks and nuns follow throughout their lives. The only difference is that laymen take such vows only for one day, and only from time to time. The Toktols required the observation of these eight vows among laypersons at least three days per month (Sergeev \& Sergeev 1998: 69). Punishment for those who broke these vows was stratified along class lines; noblemen were fined a three-year-old ram, while those of the middle and lower classes were levied a fine and inflicted with corporal punishment (a varying number of blows to the cheek) (Sergeev \& Sergeev 1998: 69). In addition, the Toktols suggest the regular recitation of the mani-in Mongolian, referring to the six-syllable mantra om manipadme hum as well as prayers in general. Recitation of the mani leads to the transformation of the mind and the empowerment of the person with compassion and kind-heartedness.

It is notable that in the Steppe Code of 1640 there are no such articles, arguably because of the relative novelty of Buddhism as a religion of practice among the Oirats. At the same time, the biography of the Oirat enlightener of the seventeenth century Zaya Pandita noted his request to the Mongolian Zasaktu Khan to promote observance of key vows and the reading of mantras: 'Order everyone to observe fasts, recite the mani, do not interfere with those who wish to [enter the religious order]' (Ratnabkhadra 2003: 167). Although fines and redemptive payments were significantly reduced in the Toktols in

16 As performed by laymen, Sojong included the observance of eight Mahayana vows: 1) not to kill; 2) not to steal; 3) to refrain from sexual acts; 4) not to deceive; 5) not to drink alcohol or consume other intoxicants (i.e. caffeine, nicotine, etc.); 6) to refrain from singing, dancing, dressing, and other embellishments of appearance (i.e. perfume and makeup); 7) to refrain from eating after noon; and 8) to refrain from high seats or luxurious accommodation. 
comparison to the Steppe Code, some fines were introduced resulting from the integration of the Kalmyks into the Russian cultural sphere and payment was increasingly required in money rather than in kind. Though one of the reasons for the revision of these penalties was the impoverishment of the Kalmyk people during the mid eighteenth century, the values central to Buddhist teaching also served to mediate the Khanate's legal approach.

\section{Buddhism in the Jinjil Decrees}

The January 1771 departure of the Kalmyks under the leadership of Ubashi Khan and the subsequent abolition of the Kalmyk Khanate radically changed the legal position of those who remained in Russia's south (Khodarkovsky 1992). The formal integration into the Astrakhan gubernaia placed the Kalmyks' religious and secular laws at odds with their political position. The decrees and declarations in Russian legislation rarely corresponded to the steppe customs of the Kalmyk people. This dissonance necessitated a further revision to secular law, one that addressed the group's needs after its more formal incorporation into the Russian state.

In 1822, the Kalmyk nobility and representatives of the high clergy gathered at Jinjil and drafted a series of eponymous decrees, which supplemented and amended traditional Kalmyk law. In practice, the results were negligible; the decrees were opposed by the Tsarist government as contradictory to imperial policy, which placed Kalmyk administration in the empire's hands (Goryaev 2014: 94).

Despite this, the 1822 decrees are relevant to the evolution of the position of Buddhism in Kalmyk secular law during the imperial period; the Jinjil decrees represent the last stage in this development. As emendations to the Steppe Code and the Toktols, the decrees were firmly grounded in pre-existing legal customs among the nomadic Kalmyks (Krueger 1972; Leontovich 1880). Religion, in addition to these pre-existing legal customs, played a central role in the formulation of the Jinjil decrees (Komandzhaev 2009). Foundationally, the decrees define the status and responsibilities of religious persons, as well as their installation into larger kinship groups: 'The head lama is installed in the specified (lit. vladel'cheskii) uluses at the choice of the ulus leader and with the consent of society; the bakshi fills the place of the lama; and where an ulus already has a lama installed but no bakshi, the next in line fills this place' (Leontovich 1880: 17-18).

Like the Mongol-Oirat Charter of 1640 , the Jinjil decrees granted the clergy significant rights and fines were prescribed for disrespectful treatment of 
lamas: 'From whoever dishonours the possessory lama (the hierarch), take eighteen cattle ... and punish with 25 blows; or, allow the lama's indulgence' (Leontovich 1880: 15). Smaller fines and punishments were stipulated for insulting other clerics. And it was forbidden to use horses belonging to either lamas or their associated khuruls except in cases of state emergency.

The Jinijl assembly introduced new rules aimed at maintaining spiritual discipline and improving the moral actions of the Kalmyk clergy. A gelung who violated one of the main commandments of Buddhism had to 'obtain a four-year-old camel for the use of the khurul' (Leontovich 1880: 19). Attention was paid in the decrees to the struggle with the imbibing of wine by religious persons, since Buddhist monastic regulations strictly forbade monks to drink alcohol. The gelungs were subject to the strictest punishment in this matter. The most negligent monks were demoted to commoners and sent to a monastery for hard labour. The Jinjil decrees lacked a consensus on monks in the process of receiving training. One article imposes the fine of one horse and transfer to the commoner estate (sosloviye). Another article limits punishment to a fine. Only repeated violations of the commandment led to the exclusion of the getsul from the religious orders: 'if a second and third time the getsul is drunk and does not repent, relegate him to the commoner class' (Leontovich 1880: 20). In general, penalties for alcohol consumption by the Buddhist clergy were strengthened in the 1822 decrees in comparison to the Toktols.

After the 1822 Jinjil decrees, the Buddhist clergy of Kalmykia no longer actively participated in the development of laws. At the same time, the legislative acts of the Russian empire with respect to the governance of the Kalmyks took into account the group's adherence to Buddhism. In 1834, the tsarist government approved the 'Regulations for the Administration of the Kalmyk People'. This legislation created the Buddhist Spiritual Directorate and tasked the Buddhist leadership in Kalmykia with updating the imperial centre about the situation in the khuruls and among believers. This regulation was preceded in 1825 by a similar one that affirmed the ability of the Kalmyk clergy to continue to follow traditional law. The Buddhist church was mainly excluded from participation in civil affairs and charged with responsibility primarily over spiritual matters - a separation of church and state occurring elsewhere in the west (family law, divorce, and oath-taking remained the sphere of the church: Schorkowitz 2001). In 1847, a revised set of regulations was issued, which abolished the Buddhist Spiritual Directorate. This also ended the zargo court, an institution composed of eight advisors to the Kalmyk khan that guided policy, determined law and supervised tax collection within the polity (Krader 1963). Instead, all religious power was concentrated in the hands of the Kalmyk head lama, who was appointed by the state with the consent of the Ministry 
of State Property. The head lama became an official in the system of imperial administration. In turn, thanks to these legal provisions, the Buddhist church in Kalmykia acquired a clear centralised structure different in form from those found in other Buddhist countries.

\section{Conclusion}

This paper provides historical depth to the interaction of Buddhism and law for the Kalmyks. Buddhist canon law had a significant impact on the evolution of legal codes drafted by the Kalmyks from the seventeenth to nineteenth centuries. The Steppe Code of 1640 can be partly understood as the adaptation of the norms set out in canonical law, particularly the Vinaya, to the secular law of the Oirats. Secular law in the Kalmyk Khanate further evolved with the legislative acts of Khan Donduk-Dashi in the 1740s, which dealt with a wide range of issues relating to the polity's religious life; many articles in the Toktols were devoted to strengthening the moral authority of the Buddhist clergy. The last legal revision considered here, the Jinjil decrees, introduced new rules aimed at maintaining the spiritual discipline and improving the mores of the Kalmyk clergy. The inclusion of Buddhist canonical law in Kalmyk legal codes served to strengthen the position of the Buddhist church in Kalmyk society. In turn, Buddhist norms began to fulfil the role of regulator of societal relations. Later in the imperial period, the Buddhist clergy in Kalmykia no longer participated in the development of laws. Instead, the legislative acts of the Russian Empire for governing the Kalmyk steppe considered the presence of Buddhism there.

In concluding, we reflect briefly on the relevance of this historical connection between Buddhism and secular law in contemporary Kalmykia. Early in the post-Soviet period, religion was declared part of state policy in Kalmykia by the republic's parliament (khural). This interval, between the removal of the article separating church and state from the republic's constitution in June 1993 and the adoption of an amended version of Article 46 two years later, was promoted by the republic's leadership as encouraging the revival of both the national religion and religion more generally (on religious revival in Kalmykia since communism's end, see Fagan 2012; Holland 2015; Sinclair 2008). In July 1993, Kalmykia's former President Kirsan Ilyumzhinov issued decree no. 145, which established the Department of Religious Affairs, co-chaired by Telo Tulku Rinpoche (Shadzhin Lama of the Kalmyk Khurul) and Father Zosima (at the time, Archbishop of the republic's Russian Orthodox Church) (on Telo Tulku Rinpoche's experience in Kalmykia during 1993-94, see Sonam \& Sarin 1994). The department's responsibilities included assistance in ensuring the 
constitutional right of citizens to practice their religion freely and the construction of religious structures necessary for practice and worship (Ochirova 2011). Ilyumzhinov also drafted a constitution referred to as the Steppe Code, drawing on the precedent of the 1640 document (Humphrey 2002). Recent revisions in Kalmykia included aligning republican law with federal law. Management of religious organisations has been taken up by the Russian Federation's Ministry of Justice. The evolution of the Kalmyk Republic's approach to religion within the context of the Russian Federation echoes the imperial experience; as the polity became more cohesive, central policy on religion superseded a regional approach that privileged Buddhism as the religion of practice and mediator of secular law.

\section{Acknowledgement}

The reported study was funded by the Russian Fund for Basic Research as part of research projects No. 16-23-03002a(m) and No. 15-03-00251.

\section{References}

Ahmad, Z. 1970. Sino-Tibetan Relations in the Seventeenth Century. Rome: Instituto Italiano per il medio ed estremo Oriente.

Bachinin, V.A. 2008. Pravo i religiya (metodologicheskie problemy sotsiokul'turnogo vzaimodeystviya) [Law and religion (methodological problems of socio-cultural interaction)]. Rossiyskiy Yuridicheskiy Zhurnal 5: 7-14.

Bakaeva, E.P. 1994. Buddizm v Kalmikii [Buddhism in Kalmykia]. Elista: Kalm. Kn. Izd-vo. Boyle, J.A. \& G.E. Wheeler. 2012. Kalmuk, in P. Bearman, Th. Bianquis, C.E. Bosworth, E. van Donzel \& W.P. Heinrichs (eds.), Encyclopaedia of Islam, Second Edition: http:// dx.doi.org/10.1163/1573-3912_islam_COM_0429. Last accessed 30 August 2017.

Casanova, J. 1994. Public Religions in the Modern World. Chicago (IL): University of Chicago Press.

Dylykov, S.D. (ed.) 1981. Ikh tsaaz ("Velikoe ulozhenie"): Pamyatnik mongol'skogo feodal'nogo prava XVII v.: Oiratskii tekst (Vvedenie $i$ kommentar) [Ik Tsaaz ("The Great Code"): The landmark of Mongol feudal law in the 17th century: Oirat text (introduction and commentary)]. Moscow: Nauka.

Eliade, M. 1959. The Sacred and the Profane: The nature of religion. New York (NY): Harcourt Brace Jovanovich.

Elverskog, J. 2006. Our Great Qing: The Mongols, Buddhism and the state in Late Imperial China. Honolulu (HI): University of Hawaii Press. 
Fagan, G. 2012. Believing in Russia. Religious policy after communism. New York (NY): Routledge.

Gazizova, V. 2009. Stupas and Their Consecration in Contemporary Kalmykia. Unpublished Master's thesis, University of Oslo.

Golstunskiy, K.F. 1880. Mongolo-Oyratskie Zakony 1640. Dopolnitel'nye Ukazy Galdan Khun-taydzhiya i Zakony, Sostavlennye dlya Volzhskikh Kalmykov pri Kalmytskom Khane Donduk-Dashi [Mongol-Oirat Laws of 1640. The additional orders of Galdan Khung-tayiji and the laws created for the Volga Kalmyks by Kalmyk Khan DondukDashi]. St Petersburg: Tip. Imper. Akad. Nauk.

Goryaev, M.S. 2014. Politika rossiyskogo pravitel'stva v Kalmykii vo vtoroy polovine XIX-nachale XX veka [Policy of the Russian government in Kalmykia in the second half of the 19th through the early 2oth century]. Izvestiya Saratovskogo Universiteta. Seriya: Istoriya. Mezhdunarodnye Otnosheniya 14: 93-100.

Grousset, R. 1970. The Empire of the Steppes: A history of central Asia. New Brunswick (NJ): Rutgers University Press.

Gurlyand, Ya.I. 1904. Stepnoe Zakonodatel'stvo s Drevneyshikh Vremen po XVII Stoletie [Steppe law from ancient times to the 17 th century]. Kazan: Tip. Imper. Uni.

Holland, E.C. 2015. Competing interpretations of Buddhism's revival in the Russian republic of Kalmykia. Europe-Asia Studies 67: 948-69.

Humphrey, C. 2002. 'Eurasia' and the political imagination in provincial Russia, in C. Hann (ed.), Postsocialism: Ideals, ideologies, and practices in Eurasia: $25^{8-76}$. New York (NY): Routledge.

Keown, D. 2004. Prātimokșa, in D. Keown (ed.), A Dictionary of Buddhism: 220-21. New York (NY): Oxford University Press.

Khodarkovsky, M. 1992. Where Two Worlds Met: The Russian state and the Kalmyk nomads, 16oo-1771. Ithaca (NY): Cornell University Press.

Khodarkovsky, M. 2002. Russia's Steppe Frontier: The making of a colonial empire, 1500180o. Bloomington (IN): Indiana University Press.

Klochkov, V.V. 1978. Religiya, Gosudarstvo, Pravo [Religion, state, law]. Moscow: Misl'.

Komandzhaev, E.A. 2009. Rasprostranenie obshcherossiyskogo zakonodatel'stva na kalmytskoe kochevoe obshchestvo v XIX v. [The prevalence of Russian legislation in Kalmyk nomadic society in the 19th century], in Sovremennoe Sostoyanie i Perspektivy Normotvorcheskoy i Pravoprimenitel'noy Deyatel'nostiv Respublike Kalmykiya [The contemporary position and perspectives of norm-setting and law enforcement in the Republic of Kalmykia]: 17-24. Elista: KGU.

Krader, L. 1963. Social Organization of the Mongol-Turkic Pastoral Nomads. The Hague: Mouton.

Krader, L. 1965. Mongol law, in J. Gilissen (ed.), Bibliographical Introduction to Legal History and Ethnology E/15: 1-22. Brussels: Université Libre de Bruxelles. 
Krueger, J.R. 1972. New materials on Oirat law and history: Part one: the Jinjil Decrees. Central Asiatic Journal 16: 194-205.

Krueger, J.R. 1975. Written Oirat and Kalmyk studies. Mongolian Studies 2: 93-113.

Kurapov, A.A. 2010. Zakonotvorcheskaya deyatel'nost' kalmytskogo buddiyskogo dukhovenstva (XVII-XIX vv.) [Legislative activity of the Kalmyk Buddhist clergy (17th-19th centuries)]. Izvestiya Ural'skogo Gosudarstvennogo Universiteta. Ser. 1, Problemy Obrazovaniya, Nauki i Kul'tury 85: 262-8.

Leontovich, F.I. 1879. K istorii prava russkikh inorodtsev: Drevnii Mongolo-Kalmytskii i Oyratskii ustav vzyskanii (Tsaadzhin Bichik) [On the history of the rights of Russian national minorities: old Mongol-Kalmyk and Oirat charter (Tsaajin-Bichig)]. Odessa: Ul'rikh.

Leontovich, F.I. 1880. Kalmytskoe pravo: Chast'I. Ulozhenie 1822 goda (tekst). Primechaniya: Sostav, istochniki i obshchii kharakter ulozheniya. Obshchestvennyi byt po kalmytskim ustavam [Kalmyk law: Part 1. Code of 1822 (text). Notes: composition, sources and general nature of the code. Public life under the Kalmyk charters]. Odessa: Ul'rikh.

Lytkin, G.S. 1969. Materialy dlya oyratov [Materials for the Oirats], in A.V. Badmaev (ed.), Kalmytskie istoriko-literaturnye pamyatniki $v$ russkom perevode [Kalmyk historical-literary landmarks in Russian translation]: 81-131. Elista: Kalmytskii Nauchno-Issledovatel'skii Institut Yazyka, Literatury i Istorii.

Miyawaki, J. 1984. The Qalqa Mongols and the Oyirad in the seventeenth century.Journal of Asian History 18: 136-73.

Morgan, D.O. 1986. The 'Great Yāsā of Chingiz Khān' and Mongol law in the Īlkhānate. Bulletin of the School of Oriental and African Studies 49: 163-76.

Morgan, D.O. 2005. The 'Great Yasa of Chinggis Khan' revisited, in R. Amitai \& M. Biran (eds.), Mongols, Turks, and Others: Eurasian nomads and the sedentary world: 291308. Leiden/Boston: Brill.

Munkh-Erdene, L. 2010. The 1640 Great Code: an Inner Asian parallel to the Treaty of Westphalia. Central Asian Survey 29: 269-88.

Ochirova, N.G. 2011. Religioznie protsessi v respublike Kalmykiya v perekhodnii period (9o-c gg. 20 veka) [Religious processes in the republic of Kalmykia in the transition period (1990s)]. Nauchnie Problemi Gumanitarnikh Issledovaniy 6: 82-8.

Pochekaev, R.Yu. 2013. Pravovye aspekty rasprostraneniya buddizma v Mongolii v XIIIXVIII vv. [The legal aspects of the spread of Buddhism in Mongolia in the 13th-18th centuries]. Strany i Narody Vostoka. Tsentral'naya Aziya i Dal'niy Vostok 34: 16-33.

Prince, J.D. 1904. The Code of Hammurabi. The American Journal of Theology 8: 601-9. Ratnabkhadra. 2003. Biografiya Zaya pandity [The biography of Zaya Pandita]. Elista: Kalm. Knizh. Izd-vo.

Riazanovsky, V.A. 1931. Mongol'skoe Pravo (Preimushchestvenno Obychnoe). [The Mongolian law (with special reference to customary law)]. Harbin: N.E. Chinareva. 
Riazonovsky, V.A. 1965. Fundamental Principles of Mongol Law. The Hague: Mouton.

Sazykin, A.G. 1980. Etiko-pravovye printsipy literatury 'narodnogo buddizma' i mongol'skie zakonoulozheniya XVII-XVIII vekov [Ethical and legal principles of works of 'folk Buddhism' and Mongolian law of the 17th and 18th centuries], in U. Erdniev (ed.), Lamaizm v Kalmykii i Voprosy Nauchnogo Ateizma [Lamaism in Kalmykia and questions of scientific atheism]: 129-37. Elista: Kalmytskii NauchnoIssledovatel'skiii Institut Istorii, Filologii i Ekonomiki.

Schorkowitz, D. 1992. Die soziale und politische Organisation bei den Kalmücken (Oiraten) und Prozesse der Akkulturation vom 17.Jahrhundert bis zur Mitte des 19.Jahrhunderts: Ethnohistorische Untersuchungen über die mongolischen Völkerschaften [The social and political organisation of the Kalmyks (Oirats) and processes of acculturation from the $17^{\text {th }}$ Ccntury to the mid 19th century: ethnohistorical studies on Mongolian peoples]. Frankfurt am Main: Peter Lang.

Schorkowitz, D. 2001. Staat und Nationalitäten in Rußland. Der Integrationsprozeß der Burjaten und Kalmücken, 1822-1925 [The state and nationalities in Russia: the integration process of the Buryats and Kalmyks, 1822-1925]. Stuttgart: Franz Steiner.

Sergeev V.S. \& B.V. Sergeev. 1998. Ugolovnoe i Grazhdanskoe Pravo Kalmykov XVII-XIX vv. (Istoriko-Pravovye Ocherki) [The criminal and civil law of the Kalmyks $17^{\text {th-19th }}$ centuries (Historical-Legal Works)]. Elista: Dzhangar.

Sinclair, T. 2008. Tibetan reform and the Kalmyk revival of Buddhism. Inner Asia 10: 241-59.

Sneath, D. 2007. The Headless State: Aristocratic orders, kinship society, and misrepresentations of nomadic Inner Asia. New York (NY): Columbia University Press.

Sonam, T. \& R. Sarin. 1994. The Trials of Telo Rinpoche. Documentary. London: British Broadcasting Corporation.

Ulanov, M.S. 2009. Buddizm v sotsiokul'turnom prostranstve Rossii [Buddhism in the sociocultural space of Russia]. Elista: Izd-vo KalmGU.

Ulanov, M.S., V.N. Badmaev \& N.P. Matsakova. 2016. Buddizm i pravovaya traditsiya v Mongolii [Buddhism and legal tradition in Mongolia]. Bylye Gody 42: 168-76.

Vernadsky, G. 1938. The scope and contents of Chingis Khan's Yasa. Harvard Journal of Asiatic Studies 3: 337-6o. 